\title{
Intervertebral Disc Degeneration and Low Back Pain: Molecular Mechanisms and Stem Cell Therapy
}

\author{
Anna Meiliana ${ }^{1,2, *}$, Nurrani Mustika Dewi ${ }^{1,2}$, Andi Wijaya $^{1,2}$ \\ ${ }^{1}$ Postgraduate Program in Clinical Pharmacy, Padjadjaran University, Jl. Eijkman No.38, Bandung, Indonesia \\ ${ }^{2}$ Prodia Clinical Laboratory, Jl. Cisangkuy No.2, Bandung, Indonesia \\ ${ }^{*}$ Corresponding author. E-mail: anna.meiliana@prodia.co.id
}

Received date: Jan 19, 2018; Revised date: Apr 8, 2018; Accepted date: Apr 18, 2018

\section{Abstract}

$\mathrm{B}$ ACKGROUND: Low back pain (LBP) mostly caused by disc degeneration, reflects to a tremendous of health care system and economy. More knowledge about these underlying pathologies will improve the opportunities that may represent critical therapeutic targets.

CONTENT: Basic research is advancing the understanding of the pathogenesis and management of LBP at the molecular and genetic levels. Cytokines such as matrix metalloproteinases, phospholipase A2, nitric oxide, and tumor necrosis factor- $\alpha$ are thought to contribute to the development of LBP. Mesenchymal stem cells (MSCs) transplant to cartilage-like cells and secrete extracellular matrix and encourage nucleus pulposus (NP) cell activity

\section{Introduction}

The lumbar intervertebral discs (IVDs) play important roles for the support and mobility of spine.(1-3) These remarkable tissues is able to maintain stability under a large variety of loading conditions, while still permitting intersegmental motion. $(1,4)$ Disc herniation and IVD degeneration (IDD) are two of the most common causes of low back pain (LBP) which is targeted for intervention.(5) Disc degeneration (DD) is a multifactorial process characterized by cellular and biochemical alternations in disc tissue which result in structural failure.(6) While DD is a part of normal inhibiting NP cell apoptosis, together with some chemical mediators such as cytokines and growth factors become a safe and effective new strategy for intervertebral disc degeneration (IDD) treatment and regeneration.

SUMMARY: IDD occurs where there is a loss of homeostatic balance with a predominantly catabolic metabolic profile. A basic understanding of the molecular changes occurring in the degenerating disc is important for practicing clinicians to help them to inform patients to alter lifestyle choices, identify beneficial or harmful supplements, or offer new biologic, genetic, or stem cell therapies.

KEYWORDS: low back pain, intervertebral disc, degeneration, nucleus pulposus, annulus fibrosus, extracellular matrix, genetic, stem cells

Indones Biomed J. 2018; 10(1): 1-15 aging, a significant number of people with indications of $\mathrm{DD}$ on magnetic resonance imaging (MRI) are actually asymptomatic, with no history of pain or disability. $(7,8)$ The risk of back pain is increasing with the severity of DD. $(9,10)$ Biological changes like proteoglycan and water loss is not really related with back pain, but back pain is more related to structural alternations, such as endplate defects and annulus height loss.(11-15) Most closely linked to pain are radial fissures in the annulus, whether or not they cause disc herniation.(14-17)

Another feature of discogenic back pain is the ingrowth of nerves and blood vessels.(18-20) Within some degenerated discs, nerves become sensitized by 
inflammatory-like reactions, so that they can signal pain after minimal mechanical stimulation in animal experiments and in pain-provocation studies on humans. $(21,22)$ The different knowledge of pain-sensitization processes may explain why some degenerated discs are painful, whereas the others are not.(23) More insights into the pathogenesis of DD may establish new paradigms for early or differential diagnostics of degeneration using new techniques such as systemic biomarkers. Research on the mechanobiology of disease also enriches the development of therapeutics for disc repair, with potential to reduce pain and disability associated with DD.(24) More recently, some studies about the application of mesenchymal stem cells (MSC) from many source for example bone marrow, synovial membrane and adipose tissues showed a promosing results for IDD.(25-27)

\section{The Lumbar IVD, Structure and Functions}

The healthy IVD is composed of some concentrically arranged layers of fibrocartilage which surround and restrain an amorphous, well-hydrated, inner core of proteoglycan gel.(1-3) Strongly bound to the vertebral bodies and cartilaginous vertebral endplates, the composite make-up of the IVD creates a hydraulic system that can absorb and transmit various combinations of compression, shear, and tensile forces. $(6,28,29)$ The healthy disc creates a "spacer effect" which maintains sufficient vertical distance between the vertebrae (disc height) to provide ligamentous tension, alignment of the facet joints, and adequate space for the passage of neurovascular structures within the vertebral foramina.(1) The IVDs lie between the vertebral bodies, linking them together (Figure 1). They are the main joints of the spinal column and occupy one-third of its height.

The foremost function of the IVD is mechanical: it transfers loads, dissipates energy and facilitates joint mobility. The IVDs are complex structures that consist of a thick outer ring of fibrous cartilage termed the annulus fibrosus (AF), which surrounds a more gelatinous core known as the nucleus pulposus (NP). The NP is sandwiched inferiorly and superiorly by cartilage endplates. (30) The NP and the AF structures act synergistically to distribute and transmit loads between the vertebral bodies (Figure 2).(31,32) The central NP containing collagen fibers and elastin fibers (Figure 3).(30) The vertebral endplate containing hyaline cartilage bonded to the perforated

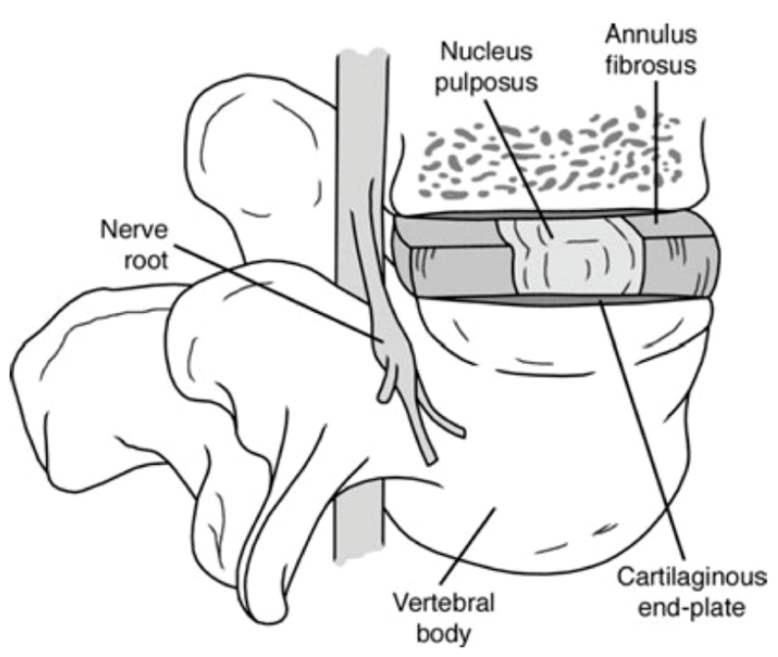

Figure 1. A line drawing of the spinal segment consisting of two vertebral bodies and a normal IVD sandwiched between them. (30) (Adapted with permission from John Wiley \& Sons).

cortical bone of the vertebral body and collagen fibers of the annulus and the nucleus (Figure 4).(30) When the disc is compressed, hydrostatic pressure is generated within the $\mathrm{NP}$, which is constrained peripherally by the AF, generating tensile circumferential stresses within the lamellar structure. $(31,32)$ Compressive loads are also supported directly by the inner AF, which is rich in proteoglycans. $(33,34)$ The angleply structure and nonlinear properties of the AF facilitate both joint mobility and stability in multiple modalities, including bending and rotation, and combinations thereof. (35-38) They provide flexibility to this, allowing bending, flexion, and torsion. $(39,40)$

Cells in the anulus are elongated parallel to the collagen fibers, rather like fibroblasts. Cells in the nucleus are initially notochordal but are gradually replaced during

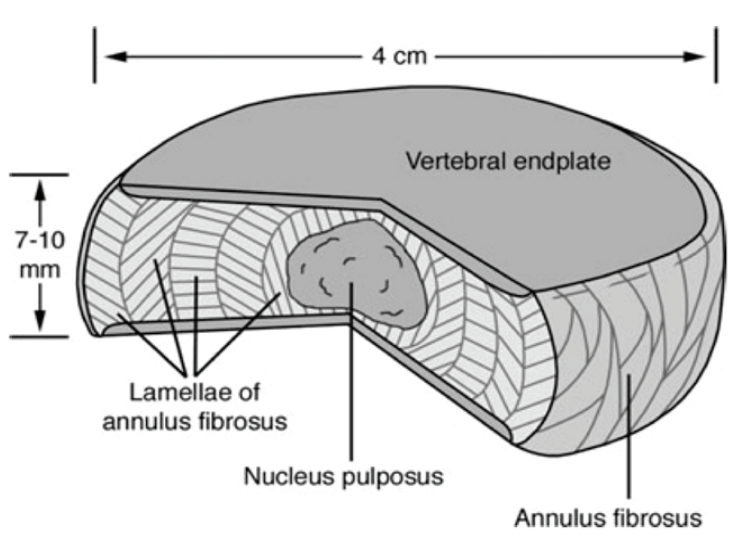

Figure 2. A cut out portion of a normal disc. Note the location of the NP, the vertebral end plate and the architecture of AF.(30) (Adapted with permission from John Wiley \& Sons). 


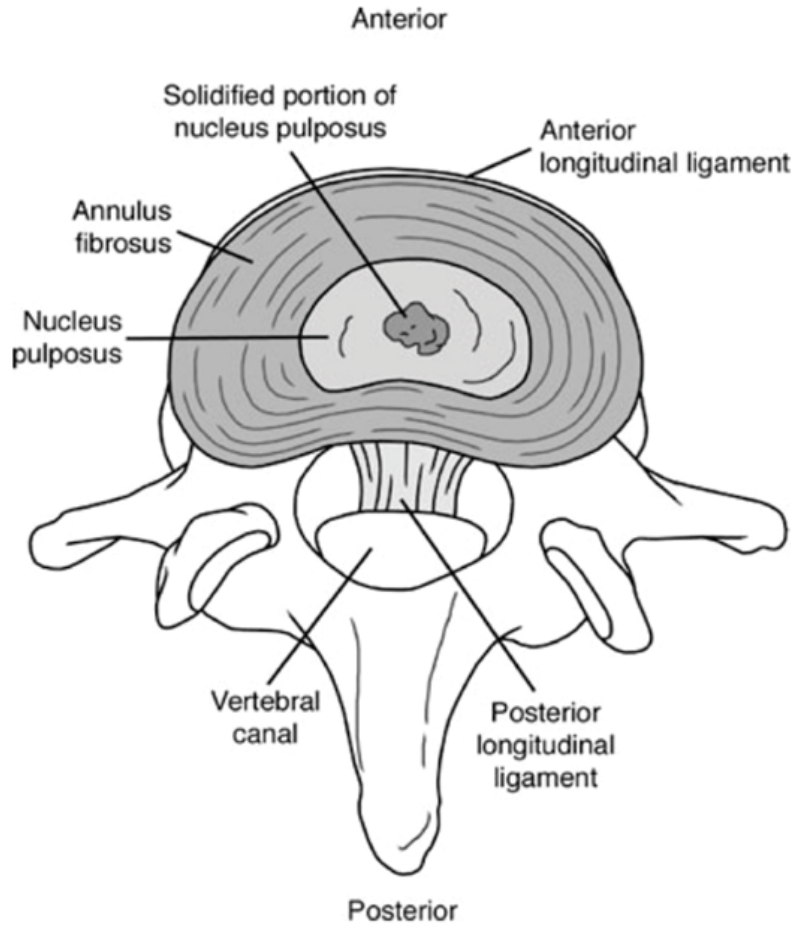

Figure 3. The central NP containing collagen fibers and elastin fibers. The solidified portion of the NP is surrounded by gel-like NP.(30) (Adapted with permission from John Wiley \& Sons).

childhood by rounded cells resembling the chondrocytes of articular cartilage. Anulus cells synthesize mostly collagen type I in response to deformation, whereas nucleus cells respond to hydrostatic pressure by synthesizing mostly proteoglycans and fine collagen type II fibrils. Cell density declines during growth (41), and in the adult is extremely low, especially in the nucleus $(42,43)$. In adult discs, blood

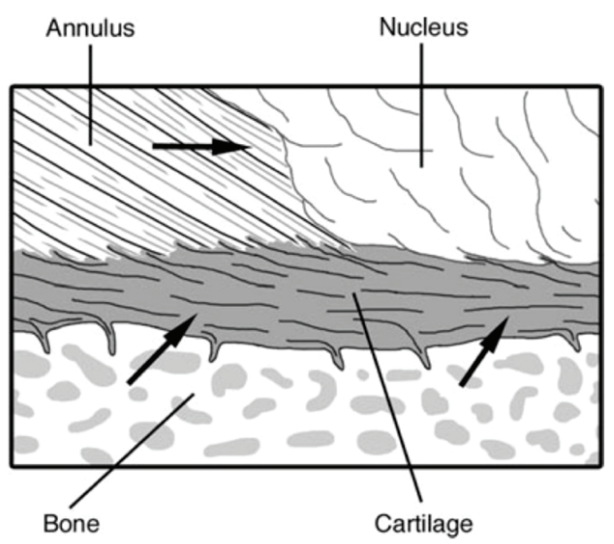

Figure 4. The organization of the vertebral endplate containing hyaline cartilage bonded to the perforated cortical bone of the vertebral body and collagen fibers of the annulus and the nucleus. Arrows indicate routes for nutrient transport from blood vessels into the central portion of the disc.(30) (Adapted with permission from John Wiley \& Sons). vessels are normally restricted to the outmost layers of the anulus. Metabolite transport is done by both diffusion, which is important for small molecules, and by bulk fluid flow, which is important for large molecules. $(42,44)$ Low oxygen tension in the center of a disc could causes anaerobic metabolism, which results in a high concentration of lactic acid and low pH.(42) In vitro experiments indicate that a chronic lack of oxygen causes nucleus cells to become quiescent, meanwhile a chronic lack of glucose can kill them.(45) Deficiencies in metabolite transport are known to limit both the density and metabolic activity of disc cells.(42) As a result, discs have limited capability to recover from any metabolic or mechanical injury. During growth and the process of aging, it is normal for endplate permeability and also disc metabolite transport to decrease, but it increase in the presence of DD and following endplate damage.(46)

Degradative enzymes, such as matrix metalloproteinases (MMPs) and a disintegrin and metalloproteinase (ADAM), are produced by disc cells to synthesize their matrix and break down the existing matrix. (47-53) Molecular markers of matrix turnover are naturally found most abundant during growth, but usually decline thereafter.(54) The major structural alternations to the disc occur during fetal and juvenile growth, when the nucleus changes in consistency from a translucent fluid to a soft amorphous tissue, caused mainly by an increase in collagen content. $(6,55)$ Collagen turnover time in articular cartilage is approximately 100 years (56) and could be even longer in the disc. Meanwhile the proteoglycan turnover is faster, possibly around 20 years (57), and some regeneration of $\mathrm{NP}$ is possible in young animals (58). Injuries that affect the inner annulus or endplate decompress the nucleus and healing processes are then overtaken by severe degenerative changes. $(59,60)$

\section{Molecular Mechanisms of IDD}

Many evidence show that the aging of the disc is related to damage from oxidative stress. Oxidative stress is known to be a driver of cellular senescence and apoptosis. Higher levels of oxidized proteins and transcription factors activated by oxidative stresses have been found in older discs compared with young discs.(61) Presence of glycalation end products, which are molecules made by non-enzymatic glycosylation and oxidation of proteins and lipids, are another prove of of age-related oxidative damage in the disc. $(62,63)$ The most common advanced glycalation end products 
in the disc are pentosidine and carboxymethyl-lysine. Pentosidine crosslinks collagen molecules and increases collagen stiffness as well as decreasing the synthesis of matrix proteins and proteoglycans.(62,64) Additionally, notochordal cells, the cells that persist in the NP, which are of notochordal origin, are greatly affected by oxidative stressors and activate both intrinsic and extrinsic pathways of apoptosis.(65) Without aging, there is reduced catabolic activity of NP cells and decreased NP cell number.(66)

Structural disruption of the IVD is manifested by a loss of the hydrostatic capacity of the nucleus that occurs when its surrounding connective tissues cannot provide adequate restraint.(6) This may occur following an injury to, or disruption of, the vertebral endplate and/or annulus. $(67,68)$ Structural changes often initially occur in small and localized regions of the IVD.(69) Figure 5 shows the classification of internal disc disruption from grade 0 to grade 5, based on the Modified Dallas Classification.

Over time, tissue disruption can spread diffusely throughout the disc and cause a reduction in stiffness and

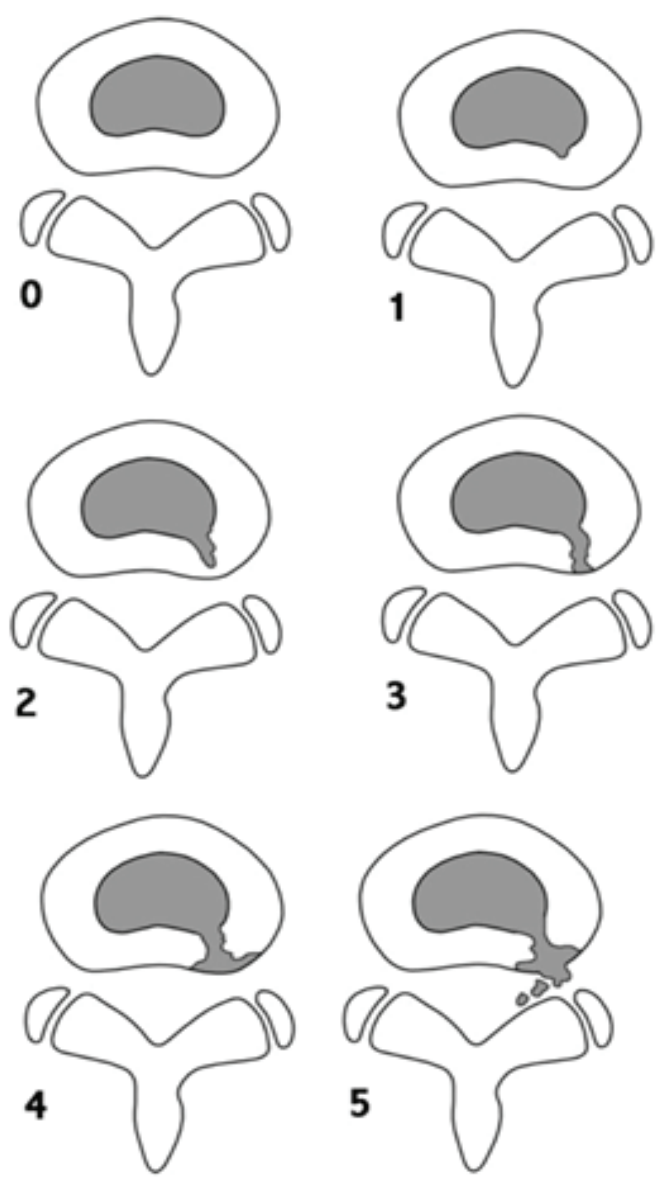

Figure 5. The classification of internal disc disruption from grade 0 to grade 5, based on the Modified Dallas Classification. (30) (Adapted with permission from John Wiley \& Sons, Inc). loss of fluid pressure, also some various combinations of bulging, herniation, and decreased disc height. $(6,70,71)$ The most significant biochemical change to occur in DD is loss of proteoglycan.(72) The aggrecan molecules become degraded, with smaller fragments being able to leach from the tissue more readily than larger portions.(30) Decreasing aggrecan content in the NP leads to reduced hydration (73), leading in turn to impaired mechanical function $(74,75)$. A less hydrated, more fibrous NP is unable to evenly distribute compressive forces between the vertebral bodies. The forces are instead transferred non-uniformly to the surrounding AF (28), which can result in altered $\mathrm{AF}$ mechanical properties $(76,77)$ and progressive structural deterioration, including the formation of circumferential and radial tears (78). On occasion, radial tears can progress to a posterior radial bulge or herniation of NP material (78), resulting in painful symptoms. Decreased disc height is also commonly associated with advanced DD (12) and results in painful compression of surrounding structures.

The vertebral endplate is believed to play a critical role in the transport of nutrients into the IVD and in the removal of waste products. $(42,79,80)$ One of the main cause of DD is thought to be failure of the nutrient supply to the disc cells.(81) Just like all cell types, the cells of the disc need nutrients, such as glucose and oxygen, to remain alive and active. The activity of disc cells is very sensitive to extracellular oxygen and $\mathrm{pH}$ in in vitro experiment, with matrix synthesis rates falling steeply at acidic $\mathrm{pH}$ and at low oxygen concentrations and the cells do not survive prolonged exposure to low $\mathrm{pH}$ or glucose concentrations. $(45,82,83)$ Decrease in nutrient supply that leads to a lowering of oxygen tension or of $\mathrm{pH}$, which arising from raised lactic acid concentrations, thus could cause the ability of disc cells to synthesize and maintain the disc's extracellular matrix and could ultimately lead to DD. Thus, endplate disruption can lead to impaired diffusion (46), disruption in nutrient supply (45), and/or cell death within the IVD, resulting from excessive tissue loading. $(29,84,85)$

Abnormal mechanical loads are also thought to provide a pathway to DD. For many decades, it was suggested that a major cause of back problems is injury, often workrelated, that causes structural damage. It is believed that such an injury initiates a pathway that leads to DD and finally to clinical symptoms and back pain.(86) Although intense exercise does not appear to affect discs adversely (87) and discs are reported to respond to some long-term loading regimens by increasing proteoglycan content (88), experimental overloading (89) or injury to the disc $(90,91)$ can induce degenerative changes. 
Significant numbers of recent works assume that the factors that lead to DD may have important genetic components. Several studies have reported a strong familial predisposition for DD and herniation.(92-94) Findings from two different twin studies conducted during the past decade showed heritability exceeding 60\%. $(95,96)$ MRI in identical twins were very similar with respect to the spinal columns and the patterns of DD.(97) Genes associated with DD have been identified. Individuals with a polymorphism in the aggrecan gene were found to be at risk for early DD. Studies of transgenic mice have demonstrated that mutations in structural matrix molecules such as aggrecan (98), collagen II (99) and collagen IX (100) can lead to DD. Mutations in genes other than those of structural matrix macromolecules have also been associated with DD.(101-103)

There is increasing evidence supporting the role of the inflammatory cytokine interleukin (IL)-1 in the processes which leads to degeneration.(104-110) During this process, there is an increase in the production of the IL-1 agonists (IL-1 $\alpha$ and IL-1 $\beta$ ) and their active receptor IL-1 receptor I (IL-1RI), without a concordant increase in the natural inhibitor, IL-1 receptor antagonist (IL-1Ra) or the decoy receptor IL-1RII within the cells of the NP and inner AF. IL-1 induces the expression of a number of MMPs and ADAM with thrombospondin motifs (ADAMTS) family members $(109,111)$, and reduces the expression of normal matrix genes.(109) Neurotrophic factor expression is modulated by IL-1 (110), and has been linked to induction of senescence in articular chondrocytes (112-113) and fibroblasts (114), all of which are features associated with IDD.(115-118)

The aforementioned evidence shows that many different influences are at work in old and DD, including genetic inheritance, impaired metabolite transport, altered levels of enzyme activity, cell senescence and death, changes in matrix macromolecules and water content, structural failure, and neurovascular ingrowth.(6)

\section{LBP Pathophysiology}

LBP is related to ageing, mechanical stresses (119) and genetic predisposition (120), and it is attributed to DD in around $40 \%$ of patients $(121,122)$. It appears that alteration in biomechanical properties of the disc structure, sensitization of nerve endings by release of chemical mediators, and neurovascular ingrowth into the degenerated discs all may contribute to the development of pain. The loss of disc structure also alters the loading response and alignment of the rest of the spinal column, including that of the facet joints, ligaments, and paraspinal muscles, which eventually may become additional pain generators.(123)

The development of pain might be the result of the presence of macrophage and mast cells that propagates the inflammatory cascade. Macrophages increase the levels of multiple inflammatory mediators, especially IL-6 and IL8 , nitric oxide, tumor necrosis factor (TNF)- $\alpha$ and IL-1 $\beta$. (124) The concentration levels of the said cytokines have correlated with pain intensity, and persistent activation of sensory fibers upregulates nitric oxide synthase, therewith increasing the level of nitric oxide, suggesting a possible positive feedback loop of pain generation.(125)

The onset of discogenic pain is characterized by nerve fiber ingrowth into an otherwise aneural tissue (Figure 6).(20,126-128) The interplay between inflammatory cytokines and neurotrophins, produced by disc cells and infiltrating immunocytes as well as neurotrophin receptors and their modulators may guide this process. Then neuronal tissue will develop after the development of vascularized granulation tissue. Degenerated disc cells secrete brain-derived growth factor (BDNF), which promotes neuronal development.(129) The release of proinflammatory cytokines IL- $1 \beta$ and TNF- $\alpha$ from the surrounding tissues also upregulates nerve growth factor (NGF) and expression of its receptors on the disc tissue. (130) Progressively small nerve fibers form along with the granulation tissue.(131) NGF promotes the collateral sprouting of additional peripheral sensory nerves into

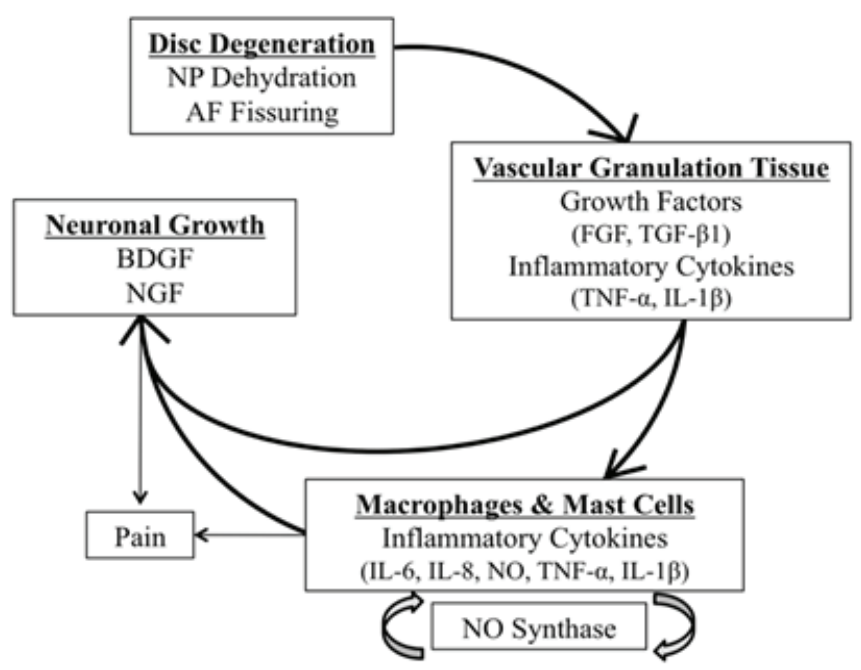

Figure 6. A series of events occur during DD that are proposed to cause discogenic pain.(126) (Springer International Publishing AG). NP: nucleus pulposus; AF: annulus fibrosus; BDNF: brainderived growth factor; NGF: nerve growth factor; FGF: fibroblast growth factor; TGF- $\beta 1$ : transforming growth factor beta 1 ; TNF- $\alpha$ : tumor necrosis factor alpha; IL: interleukin; NO: nitric oxide. 
the inner $\mathrm{AF}$ and the NP, increases nerve survival, and increases the action and sensitivity of nociceptive sensory neurons.(18-20,130,132-135)

Of note, nerve fibers that innervate disc tissue are categorized as nociceptive and thought to be derived from the dorsal root ganglia. They express acetylcholinesterase, protein gene product (PGP) 9.5, substance P (SP), BDNF, transient receptor potential cation channel subfamily $\mathrm{V}$ member 1 (TrpV1), calcitonin gene related peptide (CGRP), and neurofilament protein (NFP).(136-140) These relationships suggest a direct linkage between inflammatory cytokines, neurotrophins and nociception.(141) Mechanical stimuli which are normally innocuous to disc nociceptors can, in certain circumstances, generate an amplified response which has been termed 'peripheral sensitization'. This may explain why some degenerative discs are painful and others not. There is growing evidence that these pain receptors in painful disc are peripherally sensitized by the activity of sympathetic efferent which may initiate a pain impulse in response to ischemia, pressure changes or in amatory irritation. $(142,243)$

Knowing why nerves and blood vessels grow into AF may lead to effective strategies to hinder the process, or render it less painful. AF may reflects a microenvironment of low mechanical stress within a tissue which normally exhibits a fluid pressure many times greater than systolic blood pressure.(144,145) Normally, fluid pressure will extend from the nucleus into the inner and middle annulus (28), where it would be expected to collapse any blood vessel. Reduced pressure within a fissure is able to provide a route for ingrowth of blood vessels and accompanying nerves. In addition, proteoglycans can inhibit the growth of nerves (146) and blood vessels in vitro (147), and any loss of proteoglycans from within an annulus fissure may increase their attractiveness to ingrowing vessels.(23)

\section{Gene Therapy for IDD}

The recent standard of care for LBP due to degenerative disc changes includes non-operative approaches, such as pain management, and operative approaches. The nonoperative management aims primarily in symptomatic pain relief, while permitting possible endogenous recovery such as resolution of herniation $(148,149)$ or the repairment of structural damage $(150,151)$. The main target of nonoperative LBP management is analgesia. It is accomplished by a combination of nonsteroidal anti-inflammatory drugs
(NSAIDs) and physical therapy to strengthen core muscles among other programs. Surgical management may start with epidural injections of local anesthetic, steroids, or a combination of both prior to more invasive surgical approach.(24)

The current treatment options for IDD and the pathology associated with it are not the underlying pathophysiology. (152-155) With advances in molecular and cellular biology, researchers have start to characterize the pathophysiological pathways associated with DD and thus provided targets for potential biological treatments to augment or reverse the course of IDD.(156) Although the certain pathophysiology of DD still has not completely understood, however it is known to be affected by the interaction between various genetic, biologic and biomechanical factors.(95,157-159) The hallmark of DD is the progress loss of proteoglycans which coincides with decreases in oxygen tension, free radial accumulation, decreased $\mathrm{pH}$, and the increased activity of aberrant proteolytic enzymes.(73,160,161) With the loss of proteoglycans the NP cannot maintain normal physiologic hydrostatic pressure, resulting in in the dehydration of the disc.(162) There is also a progressive fibrosis of the NP as the ratio between type I to type II collagen increases.(163) The NP and AF lose their morphological diversity as the degeneration happens, which ultimately distracts the finely balance biomechanics of the disc and spine as whole. $(162,164)$

Numerous risk factors, such as age, abnormal physical loading, and genetics, may lead to the development of IDD (Figure 7).(165) The homeostasis of IVD tissues is biologically regulated by the active maintenance of a balance between the anabolism and catabolism of disc cells. This is achieved through a complex and precise coordination of a variety of substances, including cytokines, growth factors, enzymes and enzyme inhibitors, in a paracrine or/and autocrine fashion. $(166,167)$ The latest therapeutic strategies for DD have included some efforts in upregulating the production of key matrix proteins (e.g., aggrecan), or downregulating the catabolic events induced by the proinflammatory cytokines, IL-1 and TNF- $\alpha .(109,168-174)$

To deliver these therapeutic agents, some approaches such as protein injection and viral or non-viral gene transfer have been suggested and preclinically tested. $(167,175-177)$ The most direct approach to regenerate or repair a degenerated IVD is by injecting anabolic factors. However, there are some issues that need to be consider, such as the half-life and solubility of the factors, the proper carrier, the presence of inhibitors and some other factors. 


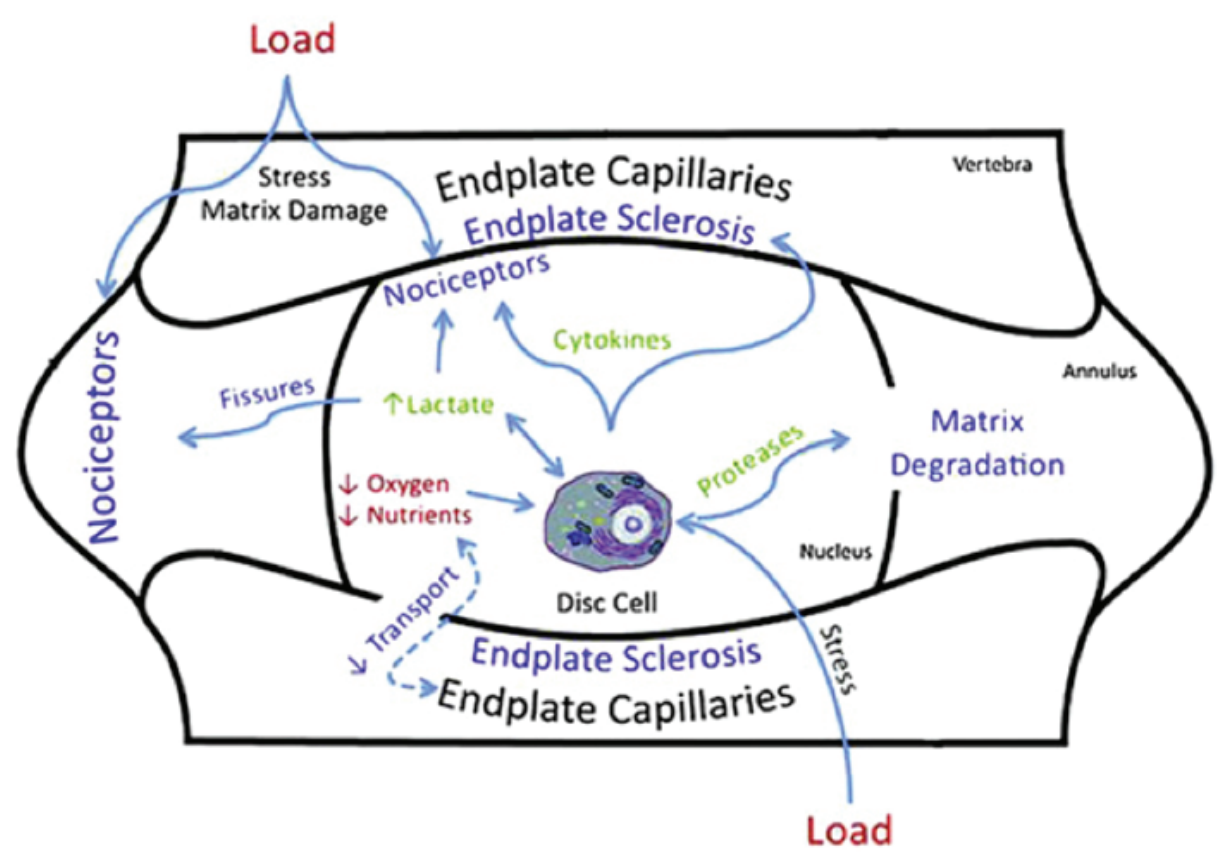

Figure 7. Numerous risk factors that may cause to the development of IDD.(165) (Adapted with permission from Elsevier).

(177) The stimulation of matrix synthesis by cytokines or growth factors changes IVD homeostasis by shifting cellular metabolism to its anabolic state.(166) It was demonstrated that the rate of synthesis of proteoglycans by IVD cells increases several-fold following the addition of transforming growth factor (TGF)- $\alpha$ and epidermal growth factor (EGF). $(178,179)$ Insulin-like growth factor (IGF)-1 also stimulates IVD cell proliferation and matrix synthesis in vitro. $(180,181)$ Members of the bone morphogenic protein (BMP) family, osteogenic protein (OP)-1 (182) and BMP-2 (183), have both been found to enhance the propylene glycol metabolism of IVD cells. OP-1 strongly stimulates the production and formation of the extracellular matrix by rabbit IVD cells (182), as well as by human IVD cells in vitro (184). OP-1 was also found to be effective in the replenishment of a matrix rich in proteoglycans and collagens after depletion of the extracellular matrix following exposure of IVD cells to IL-1 or chondroitinase ABC. $(185,186)$ BMP-2 is known to facilitates the expression of the chondrogenic phenotype by human IVD cells, increases proteoglycan synthesis and up-regulates the expression of aggrecan, collagen type I, and collagen type II mRNA, compared to untreated control levels.(187) Both recombinant human BMP (rhBMP)-2 and -12 increased human NP cell proteoglycan and collagen synthesis while having minimal effects on AF cells.(188)

Another member of the BMP family, namely growth and differentiation factor-5 (GDF-5), was also found to stimulate propylene glycol and type II collagen expression in mouse IVD cells.(189) Moreover, the recombinant human GDF-5 (rhGDF-5) enhances cell proliferation and matrix synthesis and accumulation by both bovine NP and AF cells.(190) Some epidemiologic studies highlighted that DD may be caused to a large degree by hereditary factors with apparently a relatively minor effects of environmental and behavioral risk factors (191-195), which indicated that genetic factors might play an important role in the pathogenesis of IDD.

Recently, Mayer, et al., reviewed the literature and found that the genetic polymorphisms of 21 genes have been associated with IDD, including vitamin D receptor (VDR), GDF5, aggrecan, collagen types I, IX, and XI, fibronectin, hyaluronan and proteoglycan link protein 1 (HAPLN1), thrombospondin, cartilage intermediate layer protein (CILP), asporin, MMPs1, 2, and 3, parkinson protein 2, E3 ubiquitin protein ligase (PARK2), proteosome subunit $\beta$ type 9 (PSMB9), tissue inhibitor of metalloproteinase (TIMP), cyclooxygenase-2 (COX2), and IL-1 $\alpha$, IL-1 $\beta$, and IL-6.(10,196) The idea of gene therapy originated as a means to repair the heritable genetic disorders by replacing defective genes with functional genes, which then able to cure the underlying disorder. The recent concept of gene therapy has broadened to include the transfer of exogenous genes encoding therapeutic proteins into cells to treat disease. Gene therapy changes host cell DNA, which then 
provides a mechanism for the sustained production of the desired therapeutic product.(156) The role of gene therapy in the treatment of LBP has been extensively evaluated to prevent DD disease, regenerate degenerated IVD, and promote spinal fusion.(123)

Beside the dependence of sustained expression of the therapeutic gene, the success of gene therapy also lie on the efficiency of the genetic material transfer to the host cell. With very little exceptions naked plasmid DNA alone is not an effective means of gene transfer. Therefore the use of vectors is necessary to facilitate the transfer of genetic information to host cell. There are some types of vectors, which later classified into either viral or nonviral vectors (include liposomes, gene guns, DNA-ligand complexes, and microbubble enhanced ultrasound). Liposomes are phospholipid vesicles which deliver the genetic material into the cell by fusing with the host's cellular membrane. Viral vectors use the natural ability of viruses to infect host cells and thus transfer the viral genetic information into the host. Viral vectors are very efficient at transducing the desired genetic material to the host cell, even into slowly dividing senescent cellular populations like those of the IVD. Viral vectors which is used for the gene therapy applications include adenovirus, adeno-associated virus, herpes simplex virus, lentivirus, retrovirus and also pox virus. Each viral vector is associated with specific advantages and disadvantages. Therefore proper selection of vector is critical to successful gene therapy.(156)

In addition to the selection of the appropriate gene and vector, another notable consideration with gene therapy applications is the delivery strategy utilized. There are currently two basic strategies for the delivery of exogenous therapeutic genes into target cells. The in vivo strategy involves the direct transfer of the gene-vector complex to the targeted cellular population within the living host. The ex vivo strategy differs significantly as the targeted cells are isolated and removed from the living host. These cells are then cultured with transduction of the therapeutic gene occurring in vitro. The final step includes the re-implantation of the genetically altered cells back into the host.(156)

\section{Stem Cell Therapy for IDD}

One of the available sources for cell-based repair of the disc that recently as been developed is MSC.(197-199) MSCs are a heterogeneous population of multipotent cells capable to differentiate along the chondrogenic, osteogenic, and adipogenic lineages but not the hematopoietic lineage.
Many different sources of MSCs have been identified and studied, for example bone marrow, synovial membrane and adipose tissues.(25-27)

Studies with MSC have been particularly promising. Co-culture of MSC with NP cells stimulates both NP cells proliferation and MSC differentiation toward the chondrogenic lineage.(200-203) Increased production of cytokines, particularly TGF- $\beta$ favors these transformations. (203-205) The NP contains MSC that are similar to the MSC recovered from bone marrow (206), and studies in animal models of DD have shown that MSC injected in the NP area not only survive for months but also proliferate in canine $(207,208)$, porcine (209), and rabbit models (210). Moreover, the transplanted MSC induced production of extracellular matrix proteins, including aggrecan and other proteoglycans, and types I and II collagens. $(207,209,210)$

A major limitation of using stem cells as a therapy for IDD is an appropriate delivery method that will not cause further injury to the IVD. The most direct route is an injection into the affected IVD, ensuring a localized therapeutic effect. However, in vivo studies suggest that needle injection into the IVD may cause further degeneration.(211-213) In fact, many studies use needle puncture as a model system to study DD in animals.(214-216) Recently, a population of stem cells isolated from human umbilical cord blood, multipotential stem cells (MPSCs), was reported to exhibit expanded multipotency with the ability to differentiate into cells of mesoderm, endoderm and ectoderm lineage.(217) Importantly, these cells were reported to home to sites of injury (218), and engraftment at the injured site following an intravenous injection of these cells. Contrasting to direct injection, intravenous injection neither improved the degeneration status, nor preserve disc height, however, both delivery methods increased glycosaminoglycan (GAG) protein and Acan gene expression relative to controls, suggesting possible paracrine effects.(219)

The mechanism for the inhibition of DD by MSCs most likely follows two aspects. First, MSCs can transplant to cartilage-like cells and secrete extracellular matrix. Second, MSCs can encourage NP cell activity and inhibit NP cell apoptosis.(205) Based on reported animal studies, a systematic review has showed that the use of MSCs for the treatment of DD is largely safe and effective. With the exception of 2 reports out of 24 controlled trials, no further complications were noted. According to previous studies in a rabbit model noted osteopyte formation anterolaterally to the disc space, which was attributed to leakage of the MSCs. $(220,221)$ MSC treatment seems to have a more persistent 
and consistent quality of regenerative effect. In a clinical setting, injection of MSCs has the benefit of minimizing invasiveness of secondary surgery in comparison with installation of mechanical device which also requires tertiary surgery to remove device after treatment.(216)

All the combined evidences support the application of bone marrow MSCs for regeneration of IVD and that long-term survival of injected cells in the hypoxic disc environment is feasible. In addition to MSC long-term survival in vivo, immediate and trophic effects are of great importance in supporting MSC differentiation into disc cells, contributing to immediate disc repairing. Therefore, future studies can also focus on the methods that support MSC differentiation as adjuvants. It should also be remembered that the trophic effects from MSCs injected into the IVD could potentially contribute to activate endogenous disc or stem cells to enhance the regenerative efficiency.

Extending the concept of stem cell therapy further, investigators have exploited the use of allogenic stem cells. This has the added advantage of off-the-shelf availability. Moreover, as the cause of DD is thought to be multifactorial, the use of allogenic stem cells could eliminate potential autogenic precipitating factors such as genetic predisposition (222-225), or the diminished potency of stem cells due to natural aging (197). In fact, IVD is suggested to be immuneprivileged due to its avascular nature. A study, showing allogenic NP cell transplantation did not elicit lymphocyte infiltration, is consistent with this notion.(197) The problem of immune rejection is likely to be even less for allogenic MSCs, since MSCs are capable of escaping alloantigen recognition. $(194,197)$

Adipose-tissue-derived stromal cell (ADSC) show potential for restoring degenerative discs and may prove effective in the treatment of IVD. The results of ADSC implantation studies in a DD model were promising, indicating that ADSCs could maintain their viability and proliferate within the rat IVD.(194)

Notochordal cells are the developmental origin of the NP. Yet they are not expressed in adult human IVD. Induced pluripotent stem cells (iPSCs) have demonstrated their ability to differentiate into various cell types. In IVD applications, mouse and human iPSCs have been shown to differentiate into NP-like cells expressing notochordal markers and assumed the possibility that they may be used as a novel cell source for cellular therapy.(200) Notochordal cells have been observed to substantially stimulate biosynthetic activity of NP cells through factors secreted into conditioned medium.(200) These findings support the notion that molecular agents secreted by notochordal cells constitute a promising alternative for disc repair.(24) Results of stem cell studies in IVD are developing and, if delivery obstacles can be overcome, may offer alternative future treatment strategies.

\section{Conclusion}

DD progresses with age and involves a shift in the metabolic productivity of the IVD. The degenerative and inflammatory changes occurring as the disc degenerates promote increased neural and vascular ingrowth into the disc, potentially accounting for the painful discomfort patients experience with DD. Treatments which utilize inherent growth potential, through growth factors or stem cells, can stimulate tissue repair but may also provide advantages by mitigating inflammation. By knowing the mechanism of IVD contributes an essential piece of the repair puzzle, lead to an optimum integrated management of LBP for new and refined concepts in pathophysiology, earlier detection of disease, and improved developments in tissue engineering for treatment.

\section{References}

1. Bogduk N, Twomey LT. Clinical Anatomy of the Lumbar Spine. New York: Churchill-Living-stone; 1987.

2. Humzah MD, Soames RW. Human intervertebral disc: structure and function. Anat Rec. 1988; 220: 337-56.

3. Lundon K, Bolton K. Structure and function of the lumbar intervertebral disk in health, aging, and pathologic conditions. J Orthop Sports Phys Ther. 2001; 31: 291-306.

4. Alexander LA, Hancock E, Agouris I, Smith FW, MacSween A. The response of the nucleus pulposus of the lumbar intervertebral discs to functionally loaded positions. Spine. 2007; 32: 1508-12.

5. Deyo RA, Weinstein JN. Low back pain. N Engl J Med. 2001; 344 363-70.

6. Adams MA, Roughley PJ. What is intervertebral disc degeneration, and what causes it? Spine. 2006; 31: 2151-61.

7. Boden SD, McCowin PR, Davis DO, Dina TS, Mark AS, Wiesel S. Abnormal magnetic-resonance scans of the cervical spine in asymptomatic subjects. A prospective investigation. J Bone Joint Surg Am. 1990; 72: 1178-84.

8. Jensen MC, Brant-Zawadzki MN, Obuchowski N, Modic MT, Malkasian D, Ross JS. Magnetic resonance imaging of the lumbar spine in people without back pain. N Engl J Med. 1994; 331: 69-73.

9. Cheung KM, Karppinen J, Chan D, Ho DWH, Song YQ, Sham $\mathrm{P}$, et al. Prevalence and pattern of lumbar magnetic resonance imaging changes in a population study of one thousand forty-three individuals. Spine. 2009; 34: 934-40.

10. De Schepper EIT, Damen J, van Meurs JBJ, Ginai AZ, Popham M, Hofman A, et al. The association between lumbar disc degeneration and low back pain: the influence of age, gender, and individual radiographic features. Spine. 2010; 35: 531-6. 
11. Hamanishi C, Kawabata T, Yosii T, Tanaka S. Schmorl's nodes on magnetic resonance imaging. Their incidence and clinical relevance. Spine. 1994; 19: 450-3.

12. Videman T, Battie MC, Gibbons LE, Maravilla K, Manninen H, Kaprio J. Associations between back pain history and lumbar MRI findings. Spine. 2003; 28: 582-8.

13. Boden SD, Davis DO, Dina TS, Patronas NJ, Wiesel SW. Abnormal magnetic-resonance scans of the lumbar spine in asymptomatic subjects. A prospective investigation. J Bone Joint Surg. 1990; 72: 403-8.

14. Boos N, Rieder R, Schade V, Spratt KF, Semmer N, Aebi M. The diagnostic accuracy of magnetic resonance imaging, work perception, and psychosocial factors in identifying symptomatic disc herniations. Spine. 1995; 20: 2613-25.

15. Moneta GB, Videman T, Kaivanto K, Aprill C, Spivey M, Vanharanta $\mathrm{H}$, et al. Reported pain during lumbar discography as a function of anular ruptures and disc degeneration. A re-analysis of 833 discograms. Spine. 1994; 19: 1968-74.

16. Videman T, Nurminen M. The occurrence of anular tears and their relation to lifetime back pain history: a cadaveric study using barium sulfate discography. Spine 2004; 29: 2668-76.

17. Peng B, Hou S, Wu W, Zhang C, Yang Y. The pathogenesis and clinical significance of a high-intensity zone (HIZ) of lumbar intervertebral disc on MR imaging in the patient with discogenic low back pain. Eur Spine J. 2006; 15: 583-7.

18. Freemont AJ, Peacock TE, Goupille P, Hoyland J, O'Brien J, Jayson $\mathrm{M}$, et al. Nerve ingrowth into diseased intervertebral disc in chronic back pain. Lancet. 1997; 350: 178-81.

19. Coppes MH, Marani E, Thomeer RTWM, Groen GJ. Innervation of "painful" lumbar discs. Spine. 1997; 22: 2342-9.

20. Freemont AJ, Watkins A, Le Maitre C, Baird P, Jeziorska M, Knight MTN, et al. Nerve growth factor expression and innervation of the painful intervertebral disc. J Pathol. 2002; 197: 286-92.

21. Olmarker K. Puncture of a lumbar intervertebral disc induces changes in spontaneous pain behavior: an experimental study in rats. Spine. 2008; 33: 850-5.

22. Kuslich SD, Ulstrom CL, Michael CJ. The tissue origin of low back pain and sciatica: a report of pain response to tissue stimulation during operations on the lumbar spine using local anesthesia. Orthop Clin North Am. 1991; 22: 181-7.

23. Stefanakis M, Al-Bassi M, Harding I, Pollintine P, Dolan P, Tartlon J, et al. Annulus fissures are mechanically and chemically conducive to the ingrowth of nerves and blood vessels. Spine. 2012; 37: 188391.

24. Weber KT, Jacobsen TD, Maidhof R, Virojanapa J, Overby C, Bloom $\mathrm{O}$, et al. Developments in intervertebral disc disease research: pathophysiology, mechanobiology, and therapeutics. Curr Rev Musculoscelet Med. 2015; 8: 18-31.

25. Leung VYL, Chan D, Cheung KMC. Regeneration of intervertebral disc by mesenchymal stem cells: potentials, limitations, and future direction. Eur Spine J. 2006; 15: S406-13.

26. Jeong JH, Lee JH, Jin ES, Min JK, Jeon SR, Choi KH. Regeneration of intervertebral discs in a rat disc degeneration model by implanted adipose-tissue-derived stromal cells. Acta Neurochir. 2010; 152: 1771-7.

27. Le Maitre CL, Baird P, Freemont AJ, Hoyland JA. An in vitro study investigating the survival and phenotype of mesenchymal stem cells following injection into nucleus pulposus tissue. Arthritis Res Ther. 2009; 11: R20. doi: 10.1186/ar2611.

28. Adams MA, McNally DS, Dolan P. 'Stress' distributions inside intervertebral discs. The effects of age and degeneration. J Bone Joint Surg Br. 1996; 78: 965-72.
29. Hutton WC, Elmer WA, Bryce LM, Kozlowska EE, Boden SD, Kozlowski M. Do the intervertebral disc cells respond to di erent levels of hydrostatic pressure? Clin Biomech. 2001; 16: 728-34.

30. Raj PP. Intervertebral disc: anatomy-physiology-pathophysiologytreatment. Pain Pract. 2008; 8: 18-44.

31. Johannessen W, Cloyd JM, O'Connell GD, Vresilovic EJ, Elliott DM. Trans-endplate nucleotomy increases deformation and creep response in axial loading. Ann Biomed Eng. 2006; 34: 687-96.

32. O'Connell GD, Johannessen W, Vresilovic EJ, Elliott DM. Human internal disc strains in axial compression measured noninvasively using magnetic resonance imaging. Spine. 2007; 32: 2860-8.

33. Roughley PJ, Melching LI, Heathfield TF, Pearce RH, Mort JS. The structure and degradation of aggrecan in human intervertebral disc. Eur Spine J. 2006; 15: S326-32.

34. Vresilovic EJ, Johannessen W, Elliott DM. Disc mechanics with trans-endplate partial nucleotomy are not fully restored following cyclic compressive loading and unloaded recovery. J Biomech Eng. 2006; 128: 823-9.

35. Heuer F, Schmidt H, Wilke HJ. Stepwise reduction of functional spinal structures increase disc bulge and surface strains. J. Biomech. 2008; 41: 1953-60.

36. Guerin HL, Elliott DM. Quantifying the contributions of structure to annulus fibrosus mechanical function using a nonlinear, anisotropic, hyperelastic model. J Orthop Res. 2007; 25: 508-16.

37. Schmidt H, Kettler A, Heuer F, Simon U, Claes L, Wilke HJ. Intradiscal pressure, shear strain, and fiber strain in the intervertebral disc under combined loading. Spine. 2007; 32: 748-55.

38. Smith LJ, Nerurkar NL, Choi KS, Harfe BD, Elliott DM. Degeneration and regeneration of the intervertebral disc: lessons from development. Dis Mod Mech. 2011; 4: 31-41.

39. Twomey LT, Taylor JR. Age changes in lumbar vertebrae and intervertebral discs. Clin Orthop. 1987; 224: 97-104.

40. Roberts S, Menage J, Urban JPG. Biochemical and structural properties of the cartilage end-plate and its relation to the intervertebral disc. Spine. 1989; 14: 166-74.

41. Nerlich AG, Weiler C, Weissbach S, Schaaf R, Bachmeier BE, Paesold G, et al. Age-associated changes in the cell density of the human lumbar intervertebral disc. In: The 51st Annual Meeting of the Orthopaedic Research Society; Feb 20-23, 2005; Washington, DC.

42. Urban JP, Smith S, Fairbank JC. Nutrition of the intervertebral disc. Spine. 2004; 29: 2700-9.

43. Setton LA, Chen J. Cell mechanics and mechanobiology in the intervertebral disc. Spine. 2004; 29: 2710-23.

44. Ferguson SJ, Ito K, Nolte LP. Fluid flow and convective transport of solutes within the intervertebral disc. J Biomech. 2004; 37: 213-21.

45. Horner HA, Urban JP. Effect of nutrient supply on the viability of cells from the nucleus pulposus of the intervertebral disc. Spine. 2001; 26: 2543-9.

46. Rajasekaran S, Naresh Babu J, Arun R, Armstrong BRW, Shetty AP, Murugan S. A study of diffusion in human lumbar discs. Spine. 2004; 29: 2654-67.

47. Visse R, Nagase H. Matrix metalloproteinases and tissue inhibitors of metalloproteinases: structure, function, and biochemistry. Circ Res. 2003; 92: 827-39.

48. Mott JD, Werb Z. Regulation of matrix biology by matrix metalloproteinases. Curr Opin Cell Biol. 2004; 16: 558-64.

49. Duffy MJ, Lynn DJ, Lloyd AT, O'Shea CM. The ADAMs family of proteins: from basic studies to potential clinical applications. Thromb Haemost. 2003; 89: 622-31.

50. Tang BL. ADAMTS: A novel family of extracellular matrix proteases. Int J Biochem Cell Biol. 2001; 33: 33-44. 
51. Porter S, Clark IM, Kevorkian L, Edwards DR. The ADAMTS metalloproteinases. Biochem J. 2005; 386: 15-27.

52. Roberts S, Caterson B, Menage J, Evans EH, Jaffray DC, Eisenstein SM. Matrix metalloproteinases and aggrecanase: Their role in disorders of the human intervertebral disc. Spine. 2000; 25: 300513 .

53. Goupille P, Jayson MIV, Valat JP, Freemont AJ. Matrix metalloproteinases: The clue to intervertebral disc degeneration? Spine. 1998; 23: 1612-26.

54. Antoniou J, Steffen T, Nelson F, Winterbottom N, Hollander AP, Poole RA, et al. The human lumbar intervertebral disc: evidence for changes in the biosynthesis and denaturation of the extracellular matrix with growth, maturation, ageing, and degeneration. J Clin Invest. 1996; 98: 996-1003.

55. Urban JP, Roberts S, Ralphs JR. The nucleus of the intervertebral disc from development to degeneration. Am Zool. 2000; 40: 53-61.

56. Verzijl N, DeGroot J, Thorpe SR, Bank RA, Shaw JN, Lyons TJ, et al. Effect of collagen turnover on the accumulation of advanced glycation end products. J Biol Chem. 2000; 275: 39027-31.

57. Roughley PJ. Biology of intervertebral disc aging and degeneration: Involvement of the extracellular matrix. Spine. 2004; 29: 2691-9.

58. Bradford DS, Oegema TR Jr, Cooper KM, Wakano K, Chao EY. Chymopapain, chemonucleolysis, and nucleus pulposus regeneration. A biochemical and biomechanical study. Spine. 1984; 9: $135-47$

59. Adams MA, Freeman BJ, Morrison HP, Nelson IW, Dolan P. Mechanical initiation of intervertebral disc degeneration. Spine. 2000; 25: 1625-36.

60. Kaigle AM, Holm SH, Hansson TH. Kinematic behavior of the porcine lumbar spine: A chronic lesion model. Spine. 1997; 22: 2796-806.

61. Nerlich AG, Bachmeier BE, Schleicher E, Rohrbach H, Paesold G, Boos N. Immunomorphological analysis of RAGE receptor expression and NF-kappaB activation in tissue samples from normal and degenerated intervertebral discs of various ages. Ann NY Acad Sci. 2007; 1096: 239-48.

62. Bank RA, Bayliss MT, Lafeber FP, Maroudas A, Tekoppele JM. Ageing and zonal variation in post-translational modification of collagen in normal human articular cartilage. The age-related increase in non-enzymatic glycation affects biomechanical properties of cartilage. Biochem J. 1998; 330: 345-51.

63. Sivan SS, Tsitron E, Wachtel E, Roughley P, Sakkee N, van der Ham $\mathrm{F}$, et al. Age-related accumulation of pentosidine in aggrecan and collagen from normal and degenerate human intervertebral discs. Biochem J. 2006; 399: 29-35.

64. DeGroot J, Verzij1 N, Bank RA, Lafeber FP, Bijisma JW, TeKoppele JM. Age-related decrease in proteoglycan synthesis of human articular chondrocytes: the role of nonenzymatic glycation. Arthritis Rheum. 1999; 42: 1003-9.

65. Kim KW, Ha KY, Lee JS, Rhyu KW, An HS, Woo YK. The apoptotic effect of oxidative stress and antiapoptotic effect of caspase inhibitors on rat notochordal cells. Spine. 2007; 32: 2443-8.

66. Kadow T, Sowa G, Vo N, Kang JD. Molecular basis of intervertebral disc degeneration and herniations: what are the important translational questions? Clin Orthop Relat Res. 2015; 473: 1903-12.

67. An HS, Anderson PA, Haughton VM, Iatridis JC, Kang JD, Lotz JC, et al. Introduction: disc degeneration: summary. Spine. 2004; 29 : 2677-8.

68. Kokkonen SM, Kurunlahti M, Tervonen O, Ilkko E, Vanharanta H. Endplate degeneration observed on magnetic resonance imaging of the lumbar spine: correlation with pain provocation and disc changes observed on computed tomography diskography. Spine. 2002; $27: 2274-8$
69. Johnson WE, Roberts S. Human intervertebral disc cell morphology and cytoskeletal composition: a preliminary study of regional variations in health and disease. J Anat. 2003; 203: 605-12.

70. Kirkaldy-Willis WH, Hill RJ. A more precise diagnosis for low-back pain. Spine. 1979; 4: 102-9.

71. Aoki Y, Ohtori S, Takahashi K, Ino H, Takahashi Y, Chiba T, et al. Innervation of the lumbar intervertebral disc by nerve growth factor-dependent neurons related to inflammatory pain. Spine. 2004; 29: 1077-81.

72. Lyons G, Eisenstein SM, Sweet MB. Biochemical changes in intervertebral disc degeneration. Biochim Biophys Acta. 1981; 673: 443-53.

73. Buckwalter JA. Aging and degeneration of the human intervertebral disc. Spine. 1995; 20: 1307-14.

74. Boxberger JI, Sen S, Yerramalli CS, Elliott DM. Nucleus pulposus glycosaminoglycan content is correlated with axial mechanics in rat lumbar motion segments. J Orthop Res. 2006; 24: 1906-15.

75. Costi JJ, Stokes IA, Gardner-Morse MG, Iatridis JC. Frequencydependent behavior of the intervertebral disc in response to each of six degree of freedom dynamic loading: solid phase and fluid phase contributions. Spine. 2008; 33: 1731-8.

76. Acaroglu ER, Iatridis JC, Setton LA, Foster RJ, Mow VC, Weidenbaum M. Degeneration and aging affect the tensile behavior of human lumbar anulus fibrosus. Spine. 1995; 20: 2690-701.

77. O'Connell GD, Guerin HL, Elliott DM. Theoretical and experimental evaluation of human annulus fibrosus degeneration. J Biomech Eng. 2009; 131. 111007. doi: 10.1115/1.3212104.

78. Vernon-Roberts B. Disc pathology and disease states. In: Ghosh P, editor. The Biology of the Intervertebral Disc. Boca Raton: CRC Press; 1988. p. 73-119.

79. Moore RJ. The vertebral endplate: disc degeneration, disc regeneration. Eur Spine J. 2006; 15 (Suppl 3): S333-7.

80. Roberts S, Urban JP, Evans H, Eisenstein SM. Transport properties of the human cartilage endplate in relation to its composition and calcification. Spine. 1996; 21: 415-20.

81. Nachemson A, Lewin T, Maroudas A, Freeman MAF. In vitro diffusion of dye through the end-plates and annulus fibrosus of human lumbar intervertebral discs. Acta Orthop Scand. 1970; 41: 589-607.

82. Ishihara H, Urban JP. Effects of low oxygen concentrations and metabolic inhibitors on proteoglycan and protein synthesis rates in the intervertebral disc. J Orthop Res. 1999; 17: 829-35.

83. Ohshima H, Urban JPG. Effect of lactate concentrations and $\mathrm{pH}$ on matrix synthesis rates in the intervertebral disc. Spine. 1992; 17: 1079-82.

84. Lotz JC, Chin JR. Intervertebral disc cell death is dependent on the magnitude and duration of spinal loading. Spine. 2000; 25: 1477 83.

85. Race A, Broom ND, Robertson P. Effect of loading rate and hydration on the mechanical properties of the disc. Spine. $2000 ; 25$ 662-9.

86. Allan DB, Waddell G. An historical perspective on low back pain and disability. Acta Orthop Scand Suppl. 1989; 234: 1-23.

87. Puustjarvi K, Takala T, Wang W, Tammi M, Helminen H, Inkinen R. Proteoglycans in the interverterbal disc of young dogs following strenuous running exercise. Conn Tiss Res. 1994; 30: 225-40.

88. Iatridis JC, Mente PL, Stokes IA, Aronsson DD, Alini M. Compression-induced changes in intervertebral disc properties in a rat tail model. Spine. 1999; 24: 996-1002.

89. Lotz JC, Colliou OK, Chin JR, Duncan NA, Lieben-berg E. Compression-induced degeneration of the intervertebral disc: an in vivo mouse model and finite-element study. Spine. 1998; 23: 2493506. 
90. Osti OL, Vernon-Roberts B, Fraser RD. Anulus tears and intervertebral disc degeneration. An experimental study using an animal model. Spine. 1990; 15: 762-7.

91. Lipson SJ, Muir H. Experimental intervertebral disc degeneration: morphologic and proteoglycan changes over time. Arthritis Rheum. 1981; 24: 12-21.

92. Heikkilä JK, Koskenvuo M, Heliövaara M, Kurppa K, Riihimäki H, Heikkilä $\mathrm{K}$, et al. Genetic and environmental factors in sciatica. Evidence from a nationwide panel of 9365 adult twin pairs. Ann Med. 1989; 21: 393-8.

93. Matsui H, Kanamori M, Ishihara H, Yudoh K, Naruse Y, Tsuji H. Familial predisposition for lumbar degenerative disc disease. A case-control study. Spine. 1998; 23: 1029-34.

94. Varlotta GP, Brown MD, Kelsey JL, Golden AL. Familial predisposition for herniation of a lumbar disc in patients who are less than twenty-one years old. J Bone Joint Surg Am. 1991; 73: 124-8.

95. Sambrook PN, MacGregor AJ, Spector TD. Genetic influences on cervical and lumbar disc degeneration: a magnetic resonance imaging study in twins. Arthritis Rheum. 1999; 42: 366-72.

96. Battie MC, Videman T, Gibbons LE, Fisher LD, Manninen H, Gill K. Determinants of lumbar disc degeneration. A study relating lifetime exposures and magnetic resonance imaging findings in identical twins. Spine. 1995; 20: 2601-12.

97. Battie MC, Haynor DR, Fisher LD, Gill K, Gibbons LE, Videman T. Similarities in degenerative findings on magnetic resonance images of the lumbar spines of identical twins. J Bone Joint Surg Am. 1995; 77: $1662-70$

98. Watanabe H, Nakata K, Kimata K, Nakanishi I, Yamada Y. Dwarfism and age-associated spinal degeneration of heterozygote cmd mice defective in aggrecan. Proc Natl Acad Sci USA. 1997; 94: 6943-7.

99. Li SW, Prockop DJ, Helminen H, Fassler R, Lapvetelainen T, Kiraly $\mathrm{K}$, et al. Transgenic mice with targeted inactivation of the Col2 alpha 1 gene for collagen II develop a skeleton with membranous and periosteal bone but no endochondral bone. Genes Dev. 1995; 9: 2821-30.

100. Kimura T, Nakata K, Tsumaki N, Miyamoto S, Matsui Y, Ebara S, et al. Progressive degeneration of articular cartilage and intervertebral discs. An experimental study in transgenic mice bearing a type IX collagen mutation. Int Orthop. 1996; 20: 177-81.

101. Kawaguchi Y, Kanamori M, Ishihara H, Ohmori K, Matsui H, Kimura $\mathrm{T}$. The association of lumbar disc disease with vitamin-D receptor gene polymorphism. J Bone Joint Surg Am. 2002: 84-A: 2022-8.

102. Videman T, Gibbons LE, Battie MC, Maravilla K, Vanninen E, Leppävuori J, et al. The relative roles of intragenic polymorphisms of the vitamin D receptor gene in lumbar spine degeneration and bone density. Spine. 2001; 26: E7-12.

103. Jones G, White C, Sambrook P, Eisman J. Allelic variation in the vitamin D receptor, lifestyle factors and lumbar spinal degenerative disease. Ann Rheum Dis. 1998; 57: 94-9.

104. Hoyland JA, Le MC, Freemont AJ. Investigation of the role of IL-1 and TNF in matrix degradation in the intervertebral disc. Rheumatology. 2008; 47: 809-14.

105. Sandell LJ, Xing X, Franz C, Davies S, Chang LW, Patra D. Exuberant expression of chemokine genes by adult human articular chondrocytes in response to IL-1beta. Osteoarthritis Cartilage. 2008; 16: 1560-71.

106. Le Maitre CL, Hoyland JA, Freemont AJ. Interleukin-1 receptor antagonist delivered directly and by gene therapy inhibits matrix degradation in the intact degenerate human intervertebral disc: an in situ zymographic and gene therapy study. Arthritis Res Ther. 2007; 9: R83. doi: 10.1186/ar2282.
107. Le Maitre CL, Hoyland JA, Freemont AJ. Catabolic cytokine expression in degenerate and herniated human intervertebral discs: IL-1beta and TNFalpha expression profile. Arthritis Res Ther. 2007; 9: R77. doi: 10.1186/ar2275.

108. Le Maitre CL, Freemont AJ, Hoyland JA. A preliminary in vitro study into the use of the inhibition of intervertebral disc degeneration. Int J Exp Pathol 2006; 87: 17-28.

109. Le Maitre CL, Freemont AJ, Hoyland JA. The role of interleukin-1 in the intervertebral disc degeneration. Arthritis Res Ther. 2005; 7 : R732-45.

110. Purmessur D, Freemont AJ, Holyland AJ. Expression and regulation of neurotrophins in the nondegenerate and degenerate human intervertebral disc. Arthritis Res Ther. 2008; 10: R99. doi: 10.1186/ ar2487.

111. Pockert AJ, Richardson SM, Le Maitre CL, Lyon M, Deakin JA, Buttle DJ, et al. Modified expression of the ADAMTS enzymes and tissue inhibitor of metalloproteinases 3 during human intervertebral disc degeneration. Arthritis Rheum. 2009; 60: 482-91.

112. Dai SM, Shan ZZ, Nakamura H, Masuko-Hongo K, Kato T, Nishioka $\mathrm{K}$, et al. Catabolic stress induces features of chondrocyte senescence through overexpression of caveolin 1: possible involvement of caveolin 1-induced down-regulation of articular chondrocytes in the pathogenesis of osteoarthritis. Arthritis Rheum. 2006; 54: 818-31.

113. Yudoh K, Shi Y, Karasawa R. Angiogenic growth factors inhibit chondrocyte ageing in osteoarthritis: potential involvement of catabolic stress-induced overexpression of caveolin-1 in cellular ageing. Int J Rheum Dis. 2009; 12: 90-9.

114. Dumont P, Balbeur L, Remacle J, Toussaint O. Appearance of biomarkers of in vitro ageing after successive stimulation of WI-38 fibroblasts with IL-1alpha and TNF-alpha: senescence associated beta-galactosidase activity and morphotype transition. J Anat. 2000; 197: 529-37.

115. Roberts S, Evans EH, Kletsas D, Jaffray DC, Eisenstein SM. Senescence in human intervertebral discs. Eur Spine J. 2006; 15: 312-6.

116. Gruber HE, Ingram JA, Norton HJ, Hanley EN. Senescence in cells of the aging and degenerating intervertebral disc: immunolocalization of senescence-associated beta-galactosidase in human and sand rat discs. Spine. 2007; 32: 321-7.

117. Heathfield SK, Le Maitre CL, Hoyland JA. Caveolin-1 expression and stress-induced premature senescence in human intervertebral disc degeneration. Arthritis Res Ther. 2008; 10: R87. doi: 10.1186/ ar2468.

118. Le Maitre CL, Freemont AJ, Hoyland JA. Accelerated cellular senescence in degenerate intervertebral discs: A possible role in the pathogenesis of intervertebral disc degeneration. Arthritis Res Ther. 2007; 9: R45. doi: 10.1186/ar2198.

119. Adams MA. Biomechanics of back pain. Acupunct Med. 2004; 22 : $178-88$.

120. Patel AA, Spiker WR, Daubs M, Brodke D, Cannon-Albright LA. Evidence for an inherited predisposition to lumbar disc disease. J Bone Joint Surg Am. 2011; 93: 225-9.

121. Rodrigues-Pinto R, Richardson SM, Hoyland JA. Identifcation of novel nucleus pulposus markers: Interspecies variations and implications for cell-based therapies for intervertebral disc degeneration. Bone Joint Res. 2013; 2: 169-78.

122. Capossela S, Schlafli P, Bertolo A, Janner T, Stadler BM, Potzel T, et al. Degenerated human intervertebral discs contain autoantibodies against extracellular matrix proteins. Eur Cell Mater. 2014; 27: 251-63.

123. Biyani A, Anderson GBJ. Low back pain: pathophysiology and management. J Am Acad Orthop Surg. 2004; 12: 106-15. 
124. Kim HJ, Studer RK, Sowa GA, Vo NV, Kang JD. Activated macrophage-like THP-1 cells modulate annulus fibrosus cell production of inflammatory mediators in response to cytokines. Spine. 2008; 33: 2253-9.

125. Koch A, Zacharowski K, Boehm O, Stevens M, Lipfert P, von Giesen HJ, et al. Nitric oxide and pro-inflammatory cytokines correlate with pain intensity in chronic pain patients. Inflamm Res. 2007; 56: 32-7.

126. Peng B, Wu W, Hou S, Li P, Zhang C, Yang Y. The pathogenesis of discogenic low back pain. J Bone Joint Surg Br. 2005; 87: 62-7.

127. Vernon-Roberts B, Moore RJ, Fraser RD. The natural history of age-related disc degeneration: the pathology and sequelae of tears. Spine. 2007; 32: 2797-804.

128. Melrose J, Roberts S, Smith S, Menage J, Ghosh P. Increased nerve and blood vessel ingrowth associated with proteoglycan depletion in an ovine anular lesion model of experimental disc degeneration. Spine. 2002; 27: 1278-85.

129. Freeman BJ, Fraser RD, Cain CM, Hall DJ, Chapple DC. A randomized, doubleblind, controlled trial: intradiscal electrothermal therapy versus placebo for the treatment of chronic discogenic low back pain. Spine. 2005; 30: 2369-77.

130. Abe Y, Akeda K, An HS, Aoki Y, Pichika R, Muehleman C, et al. Proinflammatory cytokines stimulate the expression of nerve growth factor by human intervertebral disc cells. Spine. 2007; 32: $635-42$.

131. Peng B, Hao J, Hou S, Wu W, Jiang D, Fu X, et al. Possible pathogenesis of painful intervertebral disc degeneration. Spine. 2006; 31: 560-6.

132. Aoki Y, Takahashi Y, Ohtori S, Moriya H, Takahashi K. Distribution and immunocytochemical characterization of dorsal root ganglion neurons innervating the lumbar intervertebral disc in rats: a review. Life Sci. 2004; 74: 2627-42.

133. Diamond J, Coughlin M, Macintyre L, Holmes M, Visheau B. Evidence that endogenous beta nerve growth factor is responsible for the collateral sprouting, but not the regeneration, of nociceptive axons in adult rats. Proc Natl Acad Sci USA. 1987; 84: 6596-600.

134. Lewin GR, Ritter AM, Mendell LM. Nerve growth factor-induced hyperalgesia in the neonatal and adult rat. J Neurosci. 1993; 13: 2136-48.

135. Woolf CJ, Ma QP, Allchorne A, Poole S. Peripheral cell types contributing to the hyperalgesic action of nerve growth factor in inflammation. J Neurosci. 1996; 16: 2716-23.

136. Ohtori S, Takahashi K, Moriya H. Existence of brain-derived neurotrophic factor and vanilloid receptor subtype 1 immunoreactive sensory DRG neurons innervating L5/6 intervertebral discs in rats. J Orthop Sci. 2003; 8: 84-7.

137. Ashton IK, Roberts S, Jaffray DC, Polak JM, Eisenstein SM. Neuropeptides in the human intervertebral disc. J Orthop Res. 1994; 12: 186-92.

138. Brown MF, Hukkanen MVJ, McCarthy ID, Redfern DRM, Batten JJ, Crock HV, et al. Sensory and sympathetic innervation of the vertebral endplate in patients with degenerative disc disease. J Bone Joint Surg Br. 1997; 79: 147-53

139. Ohtori S, Takahashi K, Chiba T, Yamagata M, Sameda H, Moriya H. Substance $P$ and calcitonin gene-related peptide immunoreactive sensory DRG neurons innervating the lumbar intervertebral discs in rats. Ann Anat. 2002; 184: 235-40.

140. García-Cosamalón J, Del Valle ME, Calavia MG, García-Suárez O, López-Muñiz A, Otero J, et al. Intervertebral disc, sensory nerves and neurotrophins: who is who in discogenic pain? J Anat. 2010; 217: $1-15$
141. Risbud MV, Shapiro IM. Role of cytokines in intervertebral disc degeneration: pain and disc-content. Nat Rev Rheumatol. 2014; 10: 44-56.

142. Edgar MA. The nerve supply of the lumbar intervertebral disc. J Bone Joint Surg Br. 2007; 89: 1135-9.

143. Peng BG. Pathophysiology, diagnosis, and treatment of discogenic low back pain. World J Orthop. 2013; 4: 42-52.

144. Sato K, Kikuchi S, Yonezawa T. In vivo intradiscal pressure measurement in healthy individuals and in patients with ongoing back problems. Spine. 1999; 24: 2468-74.

145. Nachemson AL. Disc pressure measurements. Spine. 1981; 6: 93-7.

146. Johnson WEB, Caterson B, Eisenstein SM, Hynds DL, Snow DM, Roberts S. Human intervertebral disc aggrecan inhibits nerve growth in vitro. Arthritis Rheum. 2002; 46: 2658-64.

147. Johnson WEB, Caterson B, Eisenstein SM, Roberts S. Human intervertebral disc aggrecan inhibits endothelial cell adhesion and cell migration in vitro. Spine. 2005; 30: 1139-47.

148. Guinto Jr FC, Hashim H, Stumer M. CT demonstration of disk regression after conservative therapy. AJNR Am J Neuroradiol. 1984; 5: 632-3.

149. Keskil S, Ayberk G, Evliyaoglu C, Kizartici T, Yucel E, Anbarci H. Spontaneous resolution of "protruded" lumbar discs. Minim Invasive Neurosurg. 2004; 47: 226-9.

150. Hasue M, Fujiwara M. Epidemiologic and clinical studies of longterm prognosis of low-back pain and sciatica. Spine. 1979; 4: $150-5$.

151. Komori H, Shinomiya K, Nakai O, Yamaura I, Takeda S, Furuya $\mathrm{K}$. The natural history of herniated nucleus pulposus with radiculopathy. Spine. 1996; 21: 225-9.

152. Artificial intervertebral disc arthroplasty for treatment of degenerative disc disease of the cervical spine. Technol Eval Cent Asses Program Exec Summ. 2009; 24: 1-4.

153. Bono CM, Lee CK. Critical analysis of trends in fusion for degenerative disc disease over the past 20 years: influence of technique on fusion rate and clinical outcome. Spine. 2004; 29: 455-63.

154. Hwang SL, Hwang YF, Lieu AS, Lin CL, Kuo TH, Su YF, et al. Outcome analyses of interbody titanium cage fusio used in the anterior discectomy for cervical degenerative disc disease. J Spinal Disord Tech. 2005; 18: 326-31.

155. Karasek M, Bogduk N. Twelve-month follow-up of a controlled trial of intradiscal thermal anuloplasty for back pain due to internal disc disruption. Spine. 2000; 25: 2601-7.

156. Woods BJ, Vo N, Sowa G, Kang JD. Gene therapy for intervertebral disc degeneration. Orthop Clin N Am. 2011; 42: 563-74.

157. Kelsey JL, Githens PB, Walter SD, Southwick WO, Weil U, Holford $\mathrm{TR}$, et al. An epidemiological study of acute prolapsed cervical intervertebral disc. J Bone Joint Surg Am. 1984; 66: 907-14.

158. Noponen-Hietala N, Kyllonen E, Mannikko M, Ilkko E, Karppinen J, Ott J, et al. Sequence variations in the collagen IX and XI genes are associated with degenerative lumbar spinal stenosis. Ann Rheum Dis. 2003; 62: 1208-14.

159. Pluijm SM, van Essen HW, Bravenboer N, Uitterlinden AG, Smit $\mathrm{JH}$, Pols HA, et al. Collagen type I alpha1 Sp1 polymorphism, osteoporosis, and intervertebral disc degeneration in older men and women. Ann Rheum Dis. 2004; 63: 71-7.

160. Colombini A, Lombardi G, Corsi MM, Banfi G. Pathophysiology of the human intervertebral disc. Int J Biochem Cell Biol. 2008; 40: $837-42$.

161. Urban JP, Roberts S. Degeneration of the intervertebral disc. Arthritis Res Ther. 2003; 5: 120-30.

162. Urban JP, McMullin JF. Swelling pressure of the inervertebral disc: 
influence of proteoglycan and collagen contents. Biorheology. 1985; 22: 145-57.

163. Roberts S, Evans H, Trivedi J, Menage J. Histology and pathology of the human intervertebral disc. J Bone Joint Surg Am. 2006; 88 (Suppl 2): 10-14.

164. Butler D, Trafimow JH, Andersson GB, McNeill TW, Huckman MS. Discs degenerate before facets. Spine. 1990; 15: 111-3.

165. Karppinen J, Shen FH, Luk KDK, Andersson GBJ, Cheung KMC, Samartzis D. Management of degenerative disk disease and chronic low back pain. Orthop Clin N Am. 2011; 42: 513-28.

166. Masuda K, Oegema TR Jr, An HS. Growth factors and treatment of intervertebral disc degeneration. Spine. 2004; 29: 2757-69.

167. Masuda K, An HS. Growth factors and the intervertebral disc. Spine J. 2004; 4: 330S-40S.

168. Ahn SH, Cho YW, Ahn MW, Jang SH, Sohn YK, Kim HS. mRNA expression of cytokines and chemokines in herniated lumbar intervertebral discs. Spine. 2002; 27: 911-7.

169. Burke JG, Watson RW, Conhyea D, McCormack D, Dowling FE, Walsh MG, et al. Human nucleus pulposus can respond to a proinflammatory stimulus. Spine. 3003; 28: 2685-93.

170. Kang JD, Georgescu HI, McIntyre-Larkin L, Stefanovic-Racic M, Donaldson WF 3rd, Evans CH. Herniated lumbar intervertebral discs spontaneously produce matrix metalloproteinases, nitric oxide, interleukin-6, and prostaglandin E2. Spine. 1996; 21: 271-7.

171. Weiler C, Nerlich AG, Bachmeier BE, Boos N. Expression and distribution of tumor necrosis factor alpha in human lumbar intervertebral discs: a study in surgical specimen and autopsy controls. Spine. 2005; 30: 44-53.

172. Igarashi T, Kikuchi S, Shubayev V, Myers RR. Exogenous tumor necrosis factor-alpha mimics nucleus pulposus-induced neuropathology. Molecular, histologic, and behavioral comparisons in rats. Spine. 2000; 25: 2975-80.

173. Olmarker K, Larsson K. Tumor necrosis factor alpha and nucleuspulposus-induced nerve root injury. Spine. 1999; 23: 2538-44.

174. Seguin CA, Pilliar RM, Roughley PJ, Kandel RA. Tumor necrosis factor-alpha modulates matrix production and catabolism in nucleus pulposus tissue. Spine. 2005; 30: 1940-8.

175. Masuda K, An HS. Prevention of disc degeneration with growth factors. Eur Spine J. 2006; 15(Suppl 15): 422-32.

176. Setton LA, Bonassar LJ, Masuda K. Regeneration and replacement of the intervertebral disc. In: Robert L, Robert L, Joseph V, editors. Principles of Tissue Engineering. 3rd edition. Boston: Elsevier Academic Press; 2007. p. 877-96.

177. Masuda K, An. Growth factors for intervertebral disc regeneration. In: Yue J, Bertagnoli R, McAfee P, An H, editors. Motion Preservation Surgery of The Spine: Advanced Techniques and Controversies. Philadelphia: Saunders/Elsevier; 2008. p. 649-61.

178. Thompson JP, Oegema TJ, Bradford DS. Stimulation of mature canine intervertebral disc by growth factors. Spine. 1991; 16: 25360.

179. Gruber HE, Fisher EC Jr, Desai B, Stasky AA, Hoelscher G, Hanley EN Jr. Human intervertebral disc cells from the annulus: threedimensional culture in agarose or alginate and responsiveness to TGF-beta1. Exp Cell Res. 1997; 235: 13-21.

180. Osada R, Ohshima H, Ishihara H, Yudoh K, Sakai K, Matsui H, Tsuji H. Autocrine/paracrine mechanism of insulin-like growth factor-1 secretion, and the effect of insulin-like growth factor-1 on proteoglycan synthesis in bovine intervertebral discs. J Orthop Res. 1996; 14: 690-9.

181. Masuda K. Biological repair of the degenerated intervertebral disc by the injection of growth factors. Eur Spine J. 2008; 17(Suppl 4): S441-51.
182. Masuda K, Takegami K, An H, Kumano F, Chiba K, Andersson GB, et al. Recombinant osteogenic protein-1 upregulates extracellular matrix metabolism by rabbit annulus fibrosus and nucleus pulposus cells cultured in alginate beads. J Orthop Res. 2003; 21: 922-30.

183. Yoon TS, Su Kim K, Li J, Soo Park J, Akamaru T, Elmer WA, Hutton WC. The effect of bone morphogenetic protein-2 on rat intervertebral disc cells in vitro. Spine. 2003; 28: 1773-80.

184. Imai Y, Miyamoto K, An HS, Thonar EJ, Andersson GB, Masuda K. Recombinant human osteogenic protein-1 upregulates proteoglycan metabolism of human anulus fibrosus and nucleus pulposus cells. Spine. 2007; 32: 1303-9.

185. Takegami K, Thonar EJ, An HS, Kamada H, Masuda K. Osteogenic protein-1 enhances matrix replenishment by intervertebral disc cells previously exposed to interleukin-1. Spine. 2002; 27: 1318-25.

186. Takegami K, An HS, Kumano F, Chiba K, Thonar EJ, Singh K, et al. Osteogenic protein-1 is most effective in stimulating nucleus pulposus and annulus fibrosus cells to repair their matrix after chondroitinase $\mathrm{ABC}$-induced in vitro chemonucleolysis. Spine J. 2005; 5: 231-8.

187. Kim DJ, Moon SH, Kim H, Kwon UH, Park MS, Han KJ, et al. Bone morphogenetic protein-2 facilitates expression of chondrogenic, not osteogenic, phenotype of human intervertebral disc cells. Spine. 2003; 28: 2679-84.

188. Gilbertson L, Ahn SH, Teng PN, Studer RK, Niyibizi C, Kang JD. The effects of recombinant human bone morphogenetic protein-2, recombinant human bone morphogenetic protein-12, and adenoviral bone morphogenetic protein-12 on matrix synthesis in human annulus fibrosis and nucleus pulposus cells. Spine J. 2008; 8: 449-56.

189. Li X, Leo BM, Beck G, Balian G, Anderson GD. Collagen and proteoglycan abnormalities in the GDF-5-deficient mice and molecular changes when treating disk cells with recombinant growth factor. Spine. 2004; 29: 2229-34.

190. Chujo T, An HS, Akeda K, Miyamoto K, Muehleman C, Attawia M, et al. Effects of growth differentiation factor- 5 on the intervertebral disc - in vitro bovine study and in vivo rabbit disc degeneration model study. Spine. 2006; 31: 2909-17.

191. Videman T, Leppävuori J, Kaprio J, Battié MC, Gibbons LE, Peltonen $\mathrm{L}$, et al. Intragenic polymorphisms of the vitamin D receptor gene associated with intervertebral disc degeneration. Spine. 1998; 23: 2477-85.

192. Cheung KMC, Chan D, Karppinen J, Chen Y, Jim JJT, Yip S-P, et al. Association of the Taq I allele in vitamin D receptor with degenerative disc disease and disc bulge in a Chinese population. Spine. 2006; 31: 1143-8.

193. Eser B, Cora T, Eser O, Kalkan E, Haktanır A, Erdogan MO, et al. Association of the polymorphisms of vitamin D receptor and aggrecan genes with degenerative disc disease. Genet Test Mol Biomarkers. 2010; 14: 313-7.

194. Mayer JE, Iatridis JC, Chan D, Qureshi SA, Gottesman O, Hecht AC. Genetic polymorphisms associated with intervertebral disc degeneration. Spine J. 2013; 13: 299-317.

195. Vieira LA, De Marchi PL, dos Santos AA, Christofolini DM, Barbosa CP, Fonseca FLA, et al. Analysis of FokI polymorphism of vitamin $\mathrm{D}$ receptor gene in intervertebral disc degeneration. Genet Test Mol Biomarkers. 2014; 18: 625-9.

196. Li Y, Zhu J, Gao C, Peng B. Vitamin D receptor (VDR) genetic polymorphisms associated with intervertebral disc degeneration. J Genet Genomics. 2015; 42: 135-40.

197. Chan SC, Burki A, Bonel HM, Benneker LM, Gantenbein-Ritter B. Papain-induced in vitro disc degeneration model for the study of injectable nucleus pulposus therapy. Spine J. 2013; 13: 27383. 198 
198. Zhang YG, Guo X, Xu P, Kang LL, Li J. Bone mesenchymal stem cells transplanted into rabbit intervertebral discs can increase proteoglycans. Clin Orthop Relat Res. 2005; 430: 219-26.

199. Chou AI, Reza AT, Nicoll SB. Distinct intervertebral disc cell populations adopt similar phenotypes in three-dimensional culture. Tissue Eng Part A. 2008; 14: 2079-87.

200. Vadalà G, Studer RK, Sowa G, Spiezia F, Iucu C, Denaro V, et al. Coculture of bone marrow mesenchymal stem cells and nucleus pulposus cells modulate gene expression profile without cell fusion. Spine. 2008; 33: 870-6.

201. Watanabe T, Sakai D, Yamamoto Y, Iwashina T, Serigano K, Tamura $\mathrm{F}$, et al. Human nucleus pulposus cells significantly enhanced biological properties in a coculture system with direct cell-to-cell contact with autologous mesenchymal stem cells. J Orthop Res. 2009; 28: 623. doi: 10.1002/jor.21036.

202. Yang SH, Wu CC, Shih TT, Lin FH. In vitro study on interaction between human nucleus pulposus cells and mesenchymal stem cells through paracrine stimulation. Spine. 2008; 33: 1951-7.

203. Risbud MV, Albert TJ, Guttapalli A, Vresilovic EJ, Hillibrand AS, Vaccaro AR, et al. Differentiation of mesenchymal stem cells towards a nucleus pulposus-like phenotype in vitro: Implications for cell-based transplantation therapy. Spine. 2004; 29: 2627-32.

204. Yang H, Wu J, Liu J, Ebraheim M, Castillo S, Liu X, et al. Transplanted mesenchymal stem cells with pure fibrinous gelatintransforming growth factor-beta 1 decrease rabbit intervertebral disc degeneration. Spine J. 2010; 10: 802-10.

205. Blanco JF, Graciani IF, Sanchez-Guijo FM, Muntión S, HernandezCampo P, Santamaria C, et al. Isolation and characterization of mesenchymal stromal cells from human degenerated nucleus pulposus: Comparison with bone marrow mesenchymal stromal cells from the same subjects. Spine. 2010; 35: 2259-65.

206. Hohaus C, Ganey TM, Minkus Y, Meisel HJ. Cell transplantation in lumbar spine disc degeneration disease. Eur Spine J. 2008; 17(Suppl 4): $492-503$

207. Hiyama A, Mochida J, Iwashina T, Omi H, Watanabe T, Serigano K, et al. Transplantation of mesenchymal stem cells in a canine disc degeneration model. J Orthop Res. 2008; 26: 589-600.

208. Henriksson HB, Svanvik T, Jonsson M, Hagman M, Horn M, Lindahl A, et al. Transplantation of human mesenchymal stems cells into intervertebral discs in a xenogeneic porcine model. Spine. 2009; 34 : 141-8.

209. Sakai D, Mochida J, Iwashina T, Watanabe T, Nakai T, Ando K, et al. Differentiation of mesenchymal stem cells transplanted to a rabbit degenerative disc model: Potential and limitations for stem cell therapy in disc regeneration. Spine 2005; 30: 2379-87.

210. Martin JT, Gorth DJ, Beattie EE, Harfe BD, Smith LJ, Elliott DM. Needle puncture injury causes acute and long-term mechanical deficiency in a mouse model of intervertebral disc degeneration. $\mathrm{J}$ Orthop Res. 2013; 31: 1276-82.

211. Xi Y, Kong J, Liu Y, Wang Z, Ren S, Diao Z, et al. Minimally invasive induction of an early lumbar disc degeneration model in rhesus monkeys. Spine. 2013; 38: E579-86.
212. Carragee EJ, Don AS, Hurwitz EL, Cuellar JM, Carrino J, Herzog R. Does discography cause accelerated progression of degeneration changes in the lumbar disc: a ten-year matched cohort study. Spine. 2009; 34: 2338-45.

213. Ho G, Leung VY, Cheung KM, Chan D. Effect of severity of intervertebral disc injury on mesenchymal stem cell-based regeneration. Connect Tissue Res. 2008; 49: 15-21.

214. Sakai D, Mochida J, Iwashina T, Hiyama A, Omi H, Imai M, et al. Regenerative effects of transplanting mesenchymal stem cells embedded in atelocollagen to the degenerated intervertebral disc. Biomaterials. 2006; 27: 335-45.

215. Yang F, Leung VYL, Luk KDK, Chan D, Cheung KM. Injuryinduced sequential transformation of notochordal nucleus pulposus to chondrogenic and fibrocartilaginous phenotype in the mouse. J Pathol. 2009; 218: 113-21

216. Rogers I, Yamanaka N, Bielecki R, Wong CJ, Chua S, Yuen S, et al. Identification and analysis of in vitro cultured CD45-positive cells capable of multi-lineage differentiation. Exp Cell Res. 2007; 313: 1839-52.

217. Rogers IM, Yamanaka N, Casper RF. A simplified procedure for hematopoietic stem cell amplification using a serum-free, feeder cell-free culture system. Biol Blood Marrow Transplant. 2008; 14: 927-37.

218. Tam V, Rogers I, Chan D, leung VYL, Cheung KMC. A comparison of intravenous and intradiscal delivery of multipotential stem cells on the healing of injured intervertebral disk. J Orthop Res. 2014; 32: $819-25$.

219. Sobajima S, Vadala G, Shimer A, Kim JS, Gilbertson LG, Kang JD Feasibility of a stem cell therapy for intervertebral disc degeneration. Spine J. 2008; 8: 888-96.

220. Vadalà G, Sowa G, Hubert M, Gilbertson LG, Denaro V, Kang JD. Mesenchymal stem cells injection in degenerated intervertebral disc: cell leakage may induce osteophyte formation. J Tissue Eng Regen Med. 2011; 6: 348-55.

221. Yim RLH, Lee JT, Bow CH, Meij B, Leung V, Cheung KMC, et al. A systematic review of the safety and efficacy of mesenchymal stem cells for disc degeneration: insights and future directions for regenerative therapeutics. Stem Cells Dev. 2014; 23: 2553-67.

222. Bhardwaj R, Midha R. Synchronous lumbar disc herniation in adult twins. Case report. Can J Neurol Sci. 2004; 31: 554-7.

223. Jim JJT, Noponen-Hietala N, Cheung KMC, Ott J, Karppinen $\mathrm{J}$, Sahraravand A, et al. The TRP2 allele of COL9A2 is an agedependent risk factor for the development and severity of intervertebral disc degeneration. Spine. 2005; 30: 2735-42.

224. Noponen-Hietala N, Virtanen I, Karttunen R, Schwenke S, Jakkula E, Li H, et al. Genetic variations in IL6 associate with intervertebral disc disease characterized by sciatica. Pain. 2005; 114: 186-94.

225. Semba K, Araki K, Li Z, Matsumoto K, Suzuki M, Nakagata N, et al. A novel murine gene, sickle tail, linked to the Danforth's short tail locus, is required for normal development of the intervertebral disc. Genetics. 2006; 172: 445-56. 